Article

\title{
Conversion as Negotiation. Converts as Actors of Civil Society
}

\section{Katrin Langewiesche}

Anthropology ad African Studies, Johannes Gutenberg University of Mainz, 55122 Mainz, Germany; langewie@uni-mainz.de

Received: 23 May 2020; Accepted: 26 June 2020; Published: 30 June 2020

\begin{abstract}
This article focuses on the religious movement of the Ahmadiyya and its civil society organization, Humanity First, in West-Africa and in Europe. Particular attention is paid to the place of converts within these two institutions. Conversions to an Islamic minority and the actions of this minority are studied through the prism of social commitment. I examine the intersections between religious values, the ideas of solidarity in the societies under scrutiny and, the kaleidoscopic range of Muslim charities. The paper investigates conversion as negotiation in regard to gender, social mobility, and power. Conversion is approached here as a matter of social relations and not personal belief. I argue that converts have to use various strategies of recognition, either as individuals or as a group, which places them in a permanent state of negotiation with their entourage.
\end{abstract}

Keywords: conversion; social engagement; faith-based NGO; Ahmadiyya; Burkina Faso; France

\section{Introduction}

This article examines social engagement in connection to conversion by means of the example of the religious movement of the Ahmadiyya and its civil society organization—Humanity First—both in West-Africa and in Europe. Particular attention is paid to the place of converts within these two institutions. The Ahmadiyya community, like many religious groups, is committed, alongside its religious activities, to the development of society and the care of vulnerable people. The ability to ensure social integration of the marginalized through religious self-help networks can only be analysed satisfactorily if it is seen as rooted in society as a whole. Ideas that prevail over practices of solidarity and charity are either in line with or in opposition to other normative systems of the society considered, such as the legal requirements of the state or the norms and values of kinship (Thelen et al. 2009). The manner in which social commitment is practised in religious networks is also closely linked to the presence of other religious or social providers of social solidarity such as religious NGOs, churches, and international agencies.

Likewise, conversions can only be understood in context. Although it is an intimate process, some aspects of which escape sociological apprehension, other aspects are socially determined. The logic of a conversion depends as much on the individual dispositions of converts as on their social and family relations, which generates social effects (Hervieu-Léger 1999). In a sociological perspective, therefore, it is not the individual experience that interests me to tackle in this article, but the social consequences of a conversion, more precisely of a conversion to a minority religious movement. The minority status of Ahmadiyya is mainly linked to the doctrine of this movement, described by some as heterodox, by others as non-Islamic, but also in connection to their minority demographics, whether in France and Burkina Faso, the two countries under scrutiny here, or within the overall Muslim population. Independent sources estimate that the community gathers between 10 and 20 million members 
worldwide, which approximately amounts to $1 \%$ of the world's Muslim population. ${ }^{1}$ In France, the Ahmadis represent a minority of some 2000 people, and in Burkina Faso about 65,000 according to their own estimates. ${ }^{2}$

Networking between, on the one hand, African and European Ahmadiyya communities, and on the other, Humanity First groups in Africa and Europe, are important factors in the development of the religious and social aspects of the movement. It may therefore prove insightful to examine the Ahmadi community and its NGO in two countries in Europe and Africa, where the two organizations have reached different stages and where their evolution can be surveyed.

In the first part, I present the Ahmadiyya movement and its NGO Humanity First in Burkina Faso and France. The second part investigates the intersections between religious values, the ideas of solidarity in the societies considered, and the kaleidoscopic range of Muslim charities through case studies that highlight the role of conversion as a "negotiation" with regard to gender, social mobility, and power.

\section{Fieldworks, Methodology, and Concepts}

My interest in the activities of the Ahmadiyya Muslim Community began in 2009 with a series of interviews I conducted with employees and the doctor of the Ahmadi hospital in Ouagadougou, the capital of Burkina Faso, who allowed me to participate in many medical outings in villages around the capital, in distributions of medicines in the prison, and observe cataract operations. In 2014 and 2015, I carried out systematic research in France, Germany, Burkina Faso, Ghana, and Benin, by following the activities of various Ahmadi communities and participating in their events, in particular the Jalsa Salana, an annual meeting dedicated to prayer, which is organized in every country hosting an Ahmadi community. Since 2016, I have repeatedly attended conferences, ceremonies, and festivals of the Ahmadi communities in France and Burkina Faso, as well as followed the activities of Humanity First. Since the end of 2019, I have regularly participated in the activities of Humanity First in France, particularly in Ile-de-France region, surrounding Paris.

In all these years, I have privileged biographical interviews over the collection of isolated conversion stories. The biographical approach makes it possible to identify patterns in individual religious trajectories, while preserving the singularity of each social actor (Bertaux 1980). Investigation by means of biographical narratives enables access to both autobiographical discourses and information about an individual viewed as the witness of his or her time and environment (Poirier and Raybaut 1983). However, the conversion narrative took such a place in the stories of my interlocutors that it was impossible not to dwell on it. In order to distance myself from these stories, to escape their dogmatic and standardized logic, I met the same people several times, sometimes over the course of a few months or years, and I mostly participated in meetings of Humanity First volunteers, outings to retirement homes, on occasion of their streets roaming, skype events for converts, and religious ceremonies.

The corpus on which I rely for this article is predominantly composed of interviews with women. The oldest conversions date back some twenty years. According to the terminology of the Ahmadis themselves, these are no longer "converts," but full members of the community. The status of convert is reserved to people who have embraced Ahmadiyya Islam for less than three years.

1 (Minahan 2002): 52 and World Religion Database 2016 quoted by http://a-m-l.blogspot.fr/2017/07/ahmadiyya-population-inworld-2016.html accessed 11/3/2018.

2 In Burkina Faso, Muslims represent about $60.5 \%$ of a total population of about 20 million, with a strong regional difference. The capital Ouagadougou has a population of almost 3 million, of which about 57.7\% are Muslims (Pilon et al. 2019; https://www.populationdata.net/pays/burkina-faso/). In France, the law prohibits the collection of data on ethnic or religious affiliation; however, extrapolation of existing data permits to estimate the number of Muslim citizens at 4 or 5 million, about $7.5 \%$ of the French population. The Ile-de-France region has a population of over 11 million and is home to between 12 and 15\% of Muslims (Muslims in Europe. Report by Open Society Foundations paris-20120723-EN.indd accessed 29 April 2019; Jonathan and Vaïsse 2007). 
My empirical studies are embedded in the theoretical discussion of the complex relationship between social engagement and conversion. The opposition between the merely individual and private engagement, which conversion represents in the perception of those concerned and their public engagement, calls into question the public/private opposition (Casanova 1994; Habermas 1992). The relevance of the distinction between a public and a private sphere has often been discussed (Holder 2009; Salvatore 2005). However, the notion of social engagement retains its explanatory force as a personal involvement in an action that goes beyond the individual (Le Pape 2007). Social engagement includes a wide range of actions from individual voluntary work to the professional practices of an organization. It can take the form of immediate social or humanitarian assistance, but also long-term social change with overt or secondary political objectives. At the heart of social engagement is the longing for improving the living conditions of individuals or for helping shape the future of the disadvantaged. In many cases, but certainly not always, religion plays an important role in this participatory ethic (Allahayari 2000; Molokotos-Liederman et al. 2018; Adams 2013). Analysing the reasons for individual conversion allows us to sketch the connections between the realms of the religious and of the social. The motivations evoked by converts to Ahmadi Islam highlight the close links between religious practice, spiritual aspirations, and the social life of the individual. Even if conversion "is rooted in both self and society" (Jules-Rosette 1975, p. 132), in this article, I approach conversion as a matter of social relations and not personal belief. Many authors have discussed in different-both Christian and Muslim—geographical and historical contexts the usefulness of the concept of conversion for sociological analysis, and have helped distinguish it from its theological or psychological meanings, which refer to a profound change of being. (Allievi 1999; Beckford 1989; Blakely et al. 1994; Comaroff and Comaroff 1991; Hervieu-Léger 1999; Mary 1998; Mossière 2009; Lofland and Stark 1965; Snow and Phillips 1980; Peel 1990; Van Der Veer 1996). A reflection on conversion that emphasizes its links with social commitment must recognize the variability of experiences and analyse their genesis in different social, intellectual, and religious milieus. Even if conversion is interpreted as the acceptance of a new definition of the self, as a new reference point for the construction of individual identity, it must be acknowledged that this is a new reference point that supplements others that already interact with each other (Hefner 1993; Meintel 2003; Langewiesche 1998). ${ }^{3}$ Conversion, although perceived as a radical change by those concerned, reminds us of the interdependence between two conditions. One before and one after, they mirror each other, more often than not, they impose a compromise. Similarly, a negotiation involves a compromise between parties. Each of the parties feels it gets its due in reaching an agreement, and gains satisfaction or even an advantage judged best given the circumstances. Conflictual duality has given way to a balance of forces, but not without leaving a certain residual tension. A precondition for finding common ground is the acceptance of the other in its otherness. In this sense, conversion and negotiation come together in their capacity to generate a social bond. Paraphrasing Thuderoz (2009), one could say that the contemporary process of differentiation affecting society and individuals, as well as the religious diversity of modern societies multiply conflicts, establish a permanent debate on values, and thus increase not only the need for negotiation but also potential conversions. The volume edited by de Terssac (2003) allows for the identification other points of connection between negotiation and conversion. The two notions are similar in that they develop the idea of constructing compromises and reciprocal action; they make room for identity transformations, linked to the learning that takes place in the course of interaction; and they start from the identification of a situation of uncertainty and/or conflict (Schurmans 2013). Any negotiation or conversion requires a plan, an intention. In both cases, the fulfilment of this intention produces new actors, new rules or new situations. Converts go through a process of negotiation between one condition and another that leads them to something

3 In order to emphasize the possibility of floating between several points of reference, I have proposed elsewhere the notion of "religious mobility" to complement in certain circumstances that of "conversion." (Langewiesche 2003, pp. 54-90). 
new. The conversion can then be seen as a negotiation between two statuses. Starting from this first experience of negotiation and adaptation in their personal life, converts negotiate in a second step their position in the religious group which they integrate through their social commitment and the challenges it sets for them.

Various scholars note a trend that departs from mere religious activism, and, instead, tends to combine religious and humanitarian or social commitment. This perspective makes it possible to consider the religious practices of converts in the light of the individual, social, and political constraints imposed upon them. Youth organizations of the churches or women's groups of the mosque do not confine themselves to merely religious activities anymore, but are increasingly involved in civil society (LeBlanc 2012; Soares and LeBlanc 2015). This tendency towards what Paul Gifford calls the "NGO-ization" of associations and religious groups in many African countries intensified along the 1990s. He describes this changing nature of Catholicism as a move towards becoming a development institution from a redemption one (Gifford 2015, p. 103). Many authors have studied this trend in relation to Pentecostal churches, whose connections with neoliberalism and development is widely recognized (Bornstein 2003; Freeman 2012; Coleman 2000; Gifford 2004). The Ahmadiyya founded organization, i.e., Humanity First, is one of the Muslim NGOs that illustrates, in the Islamic field, the tendency of increasing involvement of faith-based initiatives in civil societies. Petersen has related this approach to the development of Muslim faith-based Organizations as being situated in-between a "sacralised" and "secularized" form of aid (Petersen 2015). The involvement of local Muslim associations and transnational movements in education, healthcare services, and development issues penetrated into most West African countries a few years after the Catholic and Protestant initiatives were launched, and often in reaction to the latter (Langewiesche 2011; Sounaye 2011). Islam and its charities have received less attention than Christian organizations, but there is anyhow a growing number of case studies in this area (Benthall and Bellion-Jourdan 2003; Benthall 2005; Sadouni 2009; Savadogo et al. 2016; Skinner 2010; Weiss 2020). However, if there has been extensive research on the role of religious NGOs to tackle poverty in Africa or Asia, there are fewer studies on the role of Muslim NGOs working in the West, particularly in France. ${ }^{4}$

\section{Ahmadiyya and the NGO Humanity First in Burkina Faso and in France}

The Ahmadiyya Muslim Community is one branch of the Ahmadiyya founded in 1889 by Mirza Ghulam Ahmad, an Indian Muslim scholar (1835-1908). Within the group, there were theological differences and disagreements regarding the founder's successor, which prompted the splitting of the movement into two groups as early as 1914: on the one hand, the Lahore Ahmadiyya (Ahmadiyya Anjuman-i Isha'at-i Islami-AAII), and the Ahmadiyya Muslim Community (Ahmadiyya Muslim Jama'at-AMJ) on the other hand..$^{5}$ The vast majority of Ahmadis in the world today are part of the Ahmadiyya Muslim Community, whose administrative headquarters have been in London since 1984 because the Ahmadis are persecuted in their home country, Pakistan (Ahmed 2012). My investigations were limited to the Ahmadiyya Muslim Community branch of the Ahmadiyya.

The Ahmadiyya Muslim Community holds a special position within contemporary Muslim movements. Its members consider themselves Muslims, but they are not recognized as such by the majority of Muslims. There are several reasons accounting for this. The main reason is that the Ahmadis believe their founder not only is a reformer of Islam but is the promised Messiah and Imam Mahdi. Non-Ahmadi Muslims view this belief as in contradiction to the dogma that Mohammed is the "Seal of the Prophet." Beside the interpretation of the prophet's doctrine, Ahmadiyya differs from other Muslims mainly in the interpretation of the Jihad concept and the doctrine on Jesus (Lathan 2008).

4 For Switzerland: Martens (2014), for Germany: Ozkan (2012) and for England: Kroessin (2009).

5 For more details on these two branches and on the outsider situation of the Ahmadiyya Muslim Community, see Lathan (2008). 
The movement was introduced into Burkina Faso around 1950, but it became really visible in the public arena in the 2000s (Cissé and Langewiesche 2019). In West Africa, the largest Ahmadi community is now established in Ghana (Hanson 2017). In France, the Ahmadiyya Muslim Community was established in the late 1980s, after a first, unsuccessful attempt in $1946 .{ }^{6}$ The largest Ahmadi communities in Europe today are present in Great Britain and Germany (Jonker 2016; Lathan 2010).

The international Ahmadiyya Muslim Community offers a wide range of social services and charities to its members and to all people in need. However, since 1995, the religious movement has also set up a humanitarian organization: Humanity First, an NGO devoted exclusively to humanitarian aims and whose activities benefit the entire population of a country and are explicitly not associated with proselytizing. The international website of the NGO does not in any way refer to its ties with the Ahmadiyya Muslim Community, and the various national Humanity First websites do so in passing. The proximity to Islamic values can only be deduced by visitors of these websites from the actions of the NGO. In its web presentation and also in the interviews I conducted with the leaders, the organization does not define itself as an Islamic NGO (Langewiesche 2020b). It sees itself as a humanitarian association and is eager to cooperate with secular or Christian institutions and NGOs, as well as with the authorities in the countries where they operate. Humanity First was founded in 1995 by the fourth khalifa of the Ahmadiyya Muslim Community (Hazrat Mirza Tahir Ahmad). This foundation was rooted in the idea that a religious-neutral organization might give an opportunity to all "noble souls," regardless of their religious affinity, to devote themselves to a "noble task" without being eventually discouraged by the Muslim identity of the NGO (Interview Härter, 2014). Non-Ahmadis and Ahmadis therefore work together within Humanity First. Nevertheless, nearly all managers are Ahmadis as well as the vast majority of the members, particularly in Africa. In Europe not all volunteers belong to the religious community (jama'at). They are Christians, Muslims, or do not practise any religion. The Humanity First groups in the Global South are supported by Humanity First Groups in Europe or America. Most of the donations are made by members of the Ahmadiyya community, in the form of zakat (compulsory charity) or sadaqa (voluntary charity) donations. Ahmadis can settle their annual zakat donation via Humanity First, thus contributing to the dissemination of Islam through its contribution to Humanity First. In todays' context, the obligatory almsgiving becomes the source of communal and collective improvement not only for Muslims in need, but for all the needy. On the other hand, the policy of development cooperation or engagement for the needy is interpreted as a religious practice and an example of worshipping. The spiritual blessing experienced by those who devote themselves to help the Others was also clearly emphasized by the khalifa in a speech he gave in 2015:

"The benefit of serving others is such that the Promised Messiah as has aligned human compassion with spirituality by stating that loving others is a great means of worship and a way to attain Allah's blessing and rewards" (Keynote Address at the International Conference of Humanity First in the Baitul Futuh Mosque (UK) 2015).

While the Ahmadiyya Muslim Community is a missionary group committed to active proselytism, their NGO was and is still excluded from all missionary activities. In fact, I have never observed that, during or after medical activities, food distribution, or charitable visits, religious literature was being distributed or preaching was occurring. According to this understanding of separation of mission and social work, conversions to Ahmadi Islam are viewed as a by-product of the members' exemplary peaceful life and their commitment to humankind. Nevertheless, the khalifa and the tabligh (preaching) department of every country set up a "conversion scheme" based on the request of the khalifa to gain a

6 The French Ahmadiyya Muslim Community purchased their first building in 1985, where the Amir office is currently located. At that time there were no more than about twenty Ahmadis in France. The group was made up of Mauritian immigrant workers, Ahmadi by birth, and was gradually supplemented by Pakistani Ahmadi refugees, and then by Muslims of other nationalities who accepted Ahmadi Islam. In 2008 the Ahmadiyya Muslim Community inaugurated their first mosque in France in St. Prix (Val de l' Oise) (Interview Amir, May 2014). 
certain number of new members in each country. Conversion is an important task for all Ahmadis to engage with. According to the understanding of the Ahamadiyya, conversion is considered to be a training and testing process that brings the converts from the status of "non-member" to that of "active member." This process starts with a bai'hat ceremony where new followers pledge their loyalty and obedience to the khalifa and conform to the 10 conditions that will make of them full member of the Ahmadiyya. After the bai'hat every new faithful is considered a convert (naw mobaine) for the next three years. They undergo a religious training that requires a significant personal investment. The religious training of the converts as well as the guidelines constantly provided to all members are highly institutionalized and thoroughly organized. Depending on the needs of each mission centre, they organize evening courses to teach the reading of the Koran, weekend meetings of converts, discussions around the founder's writings via skype, question-and-answer sessions with the imam, courses to learn Urdu or Arabic, etc. In addition to this varied offer adapted to the specific needs of the persons interested, there is a large grey literature distributed free of charge or made available to converts. They are also invited to regularly write letters to the khalifa to establish a personal bond with the leader. ${ }^{7}$

The Ahmadiyya is a Muslim minority that must adapt their activities and priorities to the diversity of the surrounding Muslim and Christian lifestyles in order to be accepted in the host society. The stakes for a minority group lie in how it positions itself in relation to other religious groups, and competes with them in the public arena. The NGO Humanity First can be considered as a catalyser for the religious movement to be accepted by the Christian or Muslim majority.

In Burkina Faso, Humanity First is not the only Muslim NGO. Local Islamic associations, especially among the Sufi Brotherhood of Tijaniyya Hamawiyya and among the Salafis of the Mouvement Sunnite with their specific social welfare activities, have been present in Burkina since the 1970s (Audet Gosselin and Couillard 2019; Vitale 2019). Other Christian and Muslim/Christian mixed NGOs emerged in the 1970s in an attempt to respond to the dramatic droughts in the Sahel. Nowadays, every Islamic NGO is working independently even though they all are engaged in very similar projects: financing schools, orphanages, health care centres, sewing courses, constructing wells, and funding cataract operations. In Burkina Faso today, at least 20 Islamic NGOs, 40 Christian NGOs and 1 mixed NGO are operating, along with more than 300 non-religious NGOs, only in the health care sector. As a consequence, there can exist a strong competition between different NGOs as they try to obtain funding from and legitimacy within the state and international structures. While cooperation with other Muslim Groups or Islamic NGOs in Burkina is challenging for Humanity First because of the outsider position of the Ahmadiyya Muslim Community, the organization clearly expresses its willingness to cooperate with Christian or non-religious NGOs and the state. Being recognized by the state is crucial for the Amadiyya Muslim Community in order to assert themselves in relation to the Muslim majority and to gain legitimacy. By building schools and complying with the state schools' curriculum, by integrating their healthcare centres into the national scheme, Humanity First is one of the transnational Islamic NGOs that align their activities with public policy. The recognition by the state of Humanity First helps the Amadiyya to portray itself as a modern religious actor that articulates religion and progress by offering high-level education, state-of-the-art health care, and technical innovations for rural development (Langewiesche 2020b).

In France, Muslim social commitment began in the 1970s in the wake of various migratory movements, often in the suburbs of large cities such as Paris and Marseille, Lyon. As well as in Burkina Faso, Muslim social engagement started by means of local associations. Some of these associations are linked to transnational movements such as the Tabligh or the Muslim Brotherhood. Yet many of them have no specific affiliation (Bouzar 2001; Brodard 2011). Several authors have emphasized the predominance of the communitarian character of Islamic social investment in France. Neighbourhood

7 For more details about the relationship with the charismatic leader, see Langewiesche (2020c) forthcoming. 
networks, mutual aid, and solidarity directed towards a particular community were launched and gradually, from the end of the 1990s, broadened their scope to reach out society as a whole and people in need (Diop 1989; Timera 1997; Quiminal and Timéra 2002; Frégosi 2009). Since the end of the 2000s, some international Muslim organizations have earned recognition on the French public scene to tackle poverty, such as Secours Islamique France (SIF) ${ }^{8}$, Muslim Hands France ${ }^{9}$, and the Red Crescent (Benthall 2005). Compared to these NGOs, Humanity First is a small NGO that has been active in France, particularly in the Ile de France region, since 2003. Despite its small number of volunteers and its limited means, Humanity First can be compared to the large international Islamic NGOs for its professionalism and its intervention alongside secular and Christian social action. Several of my interlocutors express their wish but also difficulties to work with the local authorities' social services. As for other NGOs, their outreach to the whole of society is the basis of their recognition in France. Like all other Muslim NGOs, they are involved in helping the homeless, women in distress, and refugees. They also visit nursing homes so that the elderly feel less isolated.

What is the role of converts within Humanity First in France and Burkina Faso?

In France, $87 \%$ of Humanity First's members are Ahmadis and $13 \%$ are of other confessions or without religious affiliation, while in Burkina Faso all members of the NGO are at the same time part of the religious movement. In France and Burkina Faso, 99\% of the Ahmadiyya affiliated members of Humanity First are converts. In France, the new followers of Ahmadiyya are mostly Muslims of North African or African origin, and a minority are Christians. In France, as everywhere in Europe, the Muslim presence is linked to variations in migratory flows. In Burkina Faso, they are Burkinabé who were mainly Muslims before joining the Ahmadiyya. The sociological data of the converts requires a detailed analysis in order to shed light on the investment of individuals in society. ${ }^{10}$ The willingness to act and to influence the public authorities and other Muslim associations not only demonstrates that religious commitment is not necessarily confined to the private sector, but also makes it possible to put forward the hypothesis that religious commitment is largely dependent on the relations that the religious community maintains with other Muslim movements in its host country and with the public authorities (Le Pape 2007).

\section{Conversion as Negotiation: Gender, Social Mobility, and Power}

Two excerpts from my field logbook during roaming conducted in Paris in 2019 and in a medical camp in Maco, the central prison of Ouagadougou in 2011, allow me to underline that social engagement of converts can only be understood in the context of the associative and charitable environment in the countries in question. The two following individual stories of converts in France and in Burkina Faso, both involved with Humanity First illustrate that in contexts of religious plurality and in secular states a conversion, and the social commitment it shapes, can be interpreted as a process of negotiation in order to assert oneself vis-à-vis men, the Pakistani culture, potential employers, or the family.

"Everything is ready for our departure. The soup has been poured in bowls by the women and their children, the men carried all the bags with the snacks, thermos flasks and crates with about 100 bowls of soup in the two cars waiting at the back of the building. There is a discussion about where to start the distribution, only at the Gare de l'Est Station or already on the way. Some think that it should be distributed to all the poor people we spot, at the traffic lights, on pavement etc. Others think that it is better to concentrate on one place since there are the regulars will be waiting there. Michel ${ }^{11}$

8 SIF was member of the NGO Islamic Relief and is now independent (Lahlou 2018). Islamic Relief Worldwide was founded in 1984 by Egyptian Hany El Banna. It has become the world's largest international Islamic humanitarian organization and has branches in most Western countries.

9 Established in France since 2007 they are part of Muslim Hands International founded in the UK in 1993.

10 The research, which explains the trajectories of individuals who were not socialized in Islam and adopted it as teenagers or adults, now covers a large number of European national contexts. In contrast, very few of these studies refer to conversions to Ahmadi Islam (e.g., Wohlrab-Sahr 1999). A recent review of conversion to Islam can be found in Galonnier et al. (2019).

11 All names of volunteers and converts have been changed. 
notes that this would also make it possible to perpetuate our location in front of the Gare de l'Est station vis-à-vis the other associations that do the same kind of roaming. "Returning to the same place also increases our visibility," he argues. We still have to wait for one of the women to finish her prayer and we leave slightly late. The volunteers are worried about this delay, because they fear that the soup will have turned cold upon arrival at the Gare de l'Est Station. Traffic is still difficult because of the strikes. We learn along the way that thanks to our delayed departure we have avoided the closure of some streets. It is a miracle that Allah has sent us to bless our action, says Rachel. At Gare de l'Est the soups are distributed at full speed. This takes much less time than the preparation. On the way back one of the volunteers tells me: "It feels good to help the poor. For me, it's vital. I don't feel good if I don't do it. Sometimes I want to buy myself a nice dress, but I refrain myself and put the money I'd spend on the dress for donations. Then I feel good". Miriam explains, "It's important for us women to go out and see the effects of our actions first-hand. If it's only the boys who go out to distribute ... I mean, the ones who stay at home and are limited to fundraising, they don't understand the urgency of the needs. Personally, I want to go out into the streets and talk to women who are struggling. Men can't approach them, they're afraid of them. We must do it!" (Paris, December 2019).

Miriam refers to a recent controversy in the community regarding women's participation in the roaming organized by Humanity First. The leaders of the Ahmadiyya women's section have spoken out against women's outings, stressing the dangers of possible attacks and the risk of women ending up in inappropriate situations, in close proximity to men during these rounds. Officials are trying to use their authority within the Jama'at to deter Humanity First activists from taking homeless people off the streets. They suggest directing their engagements to other needy people such as elderly people in retirement homes. But Miriam and the other volunteers are not inclined to comply with this request. They especially want to work with women on the street or in shelters for isolated women. They interpret the attempts of the religious hierarchy to prevent them from doing so as an expression of Pakistani culture, since all the leaders are from Pakistan. "In their home country, that's why women are isolated. They only go out to go to the mosque. Don't make me believe that it is because of Islam that they stay at home in France too. It's their customs ". In spite of this disagreement, the activists try to find a compromise by making two teams, one visiting the retirement homes and the other roaming, or sometimes combining both activities during the same weekend. What appears here is the wish of these activists for a shift from the institutional, national, and vertical model to horizontal and localized operations. We also find here a recurrent discourse around the difference between "culture" and "Islam" that we can identify under different traits in the Muslim world (Ewing 2015) and among converts (Galonnier et al. 2019).

Most Humanity First volunteers are also involved in other self-help associations or have been involved for some time in other initiatives to support migrants, homeless people, women in distress, etc. But they particularly appreciate the atmosphere at Humanity First because they share the same values with the sisters and brothers of the jama'at. Some of them combine a commitment to Humanity First with responsibilities in other Ahmadi associations or within the jama'at. It is their social investment in multiple organizations and the desire to coordinate their actions with those of municipal officials that gives them a valuable knowledge of the local associative field. This knowledge allows them to adjust their places of intervention according to the other social workers on the field.

While the commitment of Humanity First volunteers is characterized by a certain versatility, as Duclos and Nicourd (2005) found for most of the associations they studied, the core group of Humanity First activists can quickly mobilize supporters in times of need-such as during the Coronavirus pandemic - through Ahmadiyya networks. All members of the religious organization are potential volunteers for the NGO. To ensure the distribution of food during the lockdown, Ahmadiyya women mobilized to prepare hundreds of sandwiches every Saturday, which Humanity First activists would collect from their homes and distribute them in the usual places. Humanity First also prepared a leaflet offering outreach services, such as running errands for neighbours. Each Ahmadiyya member could, on behalf of Humanity First, put this leaflet in the mailbox or under the door of their neighbour. 
Mireille belongs to Humanity First's hard core. As soon as she heard that a section had opened in France, she contacted the director to offer her services. Supported by her religious conviction, she uses her professional skills in fundraising and her social networking skills to manage the volunteers. She joined Humanity First two years after joining Ahmadiyya. She signed the bai'hat thanks to her younger brother who has been telling her about the jama'at for years. But some doubts about the doctrine and also an apprehension about her parents' reaction held her up for a long time. Socialized in a large, practising Muslim family, she dreaded the reaction of her relatives. Although financially independent, being married and living far from her parents, she would have appreciated the blessing, especially by her father, for her conversion to Ahmadi Islam. A few years after her father died, a dream she had one night was finally decisive for her to request an interview at the community's headquarters in France, at St. Prix, in order to obtain clarification regarding certain theological issues and an interpretation of her dream. This dream, and the following afterwards, always reassured and confirmed her in her choice, despite the virulent reaction of her uncle, her father's brother, and other members of the family. These dreams also confirmed her humanitarian impulse. Since her arrival in France, she has been committed to the poor through donations and involvement in various Catholic-inspired and public local associations. It was therefore natural for her to also participate in the humanitarian organization of Ahmadiyya. That is where she has felt surrounded by volunteers who share her vision of charity. Her commitment to the most destitute, and in particular to women in distress, in the name of her religion also allows her to highlight certain points on which her personal opinion diverges from the habits of the religious movement, such as the investment of women in the public arena, the wearing of the veil, and financial participation in the religious movement. She believes that women have a place in the streets social work, that the wearing of the veil should be adapted to life circumstances, and she prefers to make donations to Humanity First instead of participating in the financing of religious events or the running of the mosque.

Beyond its exceptionality, Mireille's story recalls the importance of dreams for converts to Ahmadiyya (Balzani 2010). All my European interlocutors refer to very strong dreams or signs, ranging from miracle to providence, to explain their decision. If Mireille committed herself only 2 years after her conversion to Humanity First, it is because no group existed previously in France. For most of the European converts I met, the commitment to Humanity First went hand in hand with their joining the religious community, sometimes it was even what triggered their conversion. The characteristics of Humanity First, the framework that the NGO offers, helps strengthen the wish to join the religious movement, to make conversion conceivable, or to reinforce the initial motivations. Mireille's experience also illustrates that in front of a centralized religious movement run by Pakistani men and women, the space where it is possible for converts to make decisions for the common good and to make collective choices remains its humanitarian and charitable section. Within the NGO, women converts need to find distinctive elements that lend legitimacy to their cause and be fairly convinced of the merits of the cause or of the possibility of bringing an additional competence to it. When dealing with men and Pakistani influence in a religious organization with well-established roles institutionalized by sub-organizations according to the age classes, separated for men and women, the converts' actions are aimed at implementing aid for women in distress by inviting everyone to participate. They argue that they are particularly suited to this task because of their gender. Thus, the gap between a liberal Islam of converts, on the one hand, and a cultural and patriarchal Islam, on the other hand, which allegedly dominates Pakistani society, is taking shape. The most militant converts ground their arguments on the one hand on their voluntary activities in the name of Islam and on the other hand on the discourse of Ahmadiyya that upholds the importance of the education (religious and scientific) of girls and their professionalization. This official discourse advocates the professionalization of women when the profession does not hinder family life and the education of 
children for whom the woman is held responsible. ${ }^{12}$ The social commitment of converts within the framework of the NGO, founded by a khalifa of the Ahmadiyya and therefore recognized and respected by the whole community, introduces new dynamics within the group, where relations between converts and non-converts are renegotiated. ${ }^{13}$

The liberating power of Ahmadi Islam for women compared to a "traditional" Islam perceived as patriarchal is also regularly named by the converts I met in Burkina Faso. In particular, they point to the fact that the vast majority of Ahmadi men are married to only one woman, although Islam allows them to take four wives. One of the converts, recently married, born into a practising Muslim family and converted to Ahmadi Islam two years ago, elicits this idea: "You know, any woman would like to be alone in her home. Now, if he tells me his reasons for taking a second wife, and they are valid, I would not object. If not, it would be against the prescriptions of the Koran. But at least, with the jama'at, I have been told what the valid reasons are. Today, it is still difficult to justify taking two, three, or four wives. In any case, I would know how to argue!" The involvement of women in Ahmadi Islam and the issues of polygamy and women's rights in general are a way for them to question the reading of Islam in which the tradition inherited by their fathers endeavoured to confine them. By also drawing on Islam or seeking support from the Koran, they allow themselves to follow a line of reasoning that is more in line with their interests (Timera 1997).

In Burkina Faso, contrary to France, most of Humanity First's activities are located in rural areas. However, when there is an emergency such as in the case of the 2009 floods in Ouagadougou, the Covid-19 health crisis, or when a particular request is made, the NGO also launch operations in the city. The intervention in which I participated in the central prison of Ouagadougou (Maco) was initiated by a request addressed to the doctor of the Ahmadi hospital.

"Five of us are leaving for Maco. The Doctor, the driver, the doctor's assistant, one of the Ahmadiyya students staying at the mission who is a volunteer for Humanity First, and me. Before starting the car, the doctor pronounces a short prayer to call on Allah's mercy. He explains to me that he does not undertake any medical or social action without first praying. The trunk is full of medicines. We make our way into the courtyard of Maco very easily and carry our medicines to the inner courtyard of the male inmates. Dozens of them line up behind the table set up by the doctor. He asks: where does it hurt? in your head, ok give him paracetamol. In the belly, okay, give him an antiseptic. Sometimes, when we can see from the patient's face that he didn't understand what the doctor says, Issa translates it into Moore, sometimes into Fulfulde. The head of the medical staff of Maco attends the scene without intervening. He beckons me not to leave the table. A prisoner comes up, asking in perfect French for glasses. The doctor advises him to go and see the Protestants next time they visit Maco. He considers they can offer ophthalmological care. He notes on a sheet of paper the names of the patients in need of cataract surgery. He turns to the head of staff: "We will soon have cataract specialists at the Centre. Maybe these people could benefit from our free operations?" One hour later, the drugs have all been distributed and we're on our way. In the car, the doctor asks Issa how many cards he has distributed. They draw up their statistics by means of these cards. Today he distributed 200. The doctor speaks to the Humanity First student and says: "You can write this down in your report. I'll give you more details at the office" (Ouagadougou, November 2011).

Unlike food distribution in Paris where all participants are volunteers, medicine distribution in Ouagadougou also includes two hospital employees who get paid. In both cases, social action takes place after spiritual exercises. In particular, prayer serves as a support for commitment. Pleasing God and being faithful to Islam are motivations clearly or implicitly mentioned by the actors. Social action

12 A high percentage of Ahmadi girls have earned university degrees, particularly in England and Germany, where the majority of them still originate from the Pakistani immigrant community. The local Education (Ta'lim) Department of every Jama'at supervises the academic progression of each member, organizes students counselling, religious classes and education seminars which provide guidance for pupils and their parents.

13 On the dynamics of change that converts bring to a religious group see (Setta 1999; Allievi 1999; Kepel 1991). 
is elevated to the rank of religious practice. An important goal that motivates social commitment is seeking God's favour, as much for the doctor as for the French volunteers. Assistance to the poor and the marginalized populations give the opportunity to perfect one's spiritual progress. Psychological factors, such as feeling good when helping others and feeling guilty when not helping others, are often named as determinants for one's involvement in charitable work.

Everywhere, Humanity First defends the impartiality of its action for the benefit of all people in need, the same way public institutions operate. In practice, whether in Burkina Faso or in France, people in need often have a link with volunteers, with their interests and constraints. This was the case for choosing retirement homes in the Ile de France region, which was based on personal acquaintances of the managers or animators with some of the NGO's activists. Similarly, the intervention at Maco in Ouagadougou was organized because the doctor and the head of the medical staff of the prison knew each other. The medical camps set up by Humanity First in the villages of Burkina Faso are always carried out by means of the Ahmadiyya missionaries who are in charge of the area concerned. Personal links can also be made through social networks, as they act as a relay between people in need and those willing to support them. As a result, the case of a person in need is presented to the group, which then seeks to establish a direct link with that person. After discussing the case, the group decides whether or not to support the person morally or materially. During the lockdown in France this was a common modus operandi.

During the activities in Ouagadougou and Paris, the collaboration between members of Humanity First and those of other faith-based or public organizations has developed. In a difficult religious context, as it is the case in Burkina Faso since the terrorist attacks of 2016, inter-religious relations are particularly underscored in the media and their "dialogue" is valued. ${ }^{14}$ Ahmadiyya has a long tradition of theological debate with representatives of different religions (Langewiesche 2020a). Humanity First puts these theological aspirations into practice by seeking concrete collaboration with NGOs of different faiths. For example, in Burkina Faso Humanity First is associated with one-dollar-glasses, a secular NGO and the Ministry of Health for healthcare actions. If such cooperation is carried out with lay, Catholic, or Protestant structures, collaborating with Muslim associations is more complicated due to the outsider position of Ahmadiyya. The openness towards other religions is one of their features that attracted Ibrahim both to Ahmadi Islam and to Humanity First.

Ibrahim came to know the Ahmadiyya Muslim Community of Burkina Faso through his uncle, with whom he grew up in a town in northern Burkina Faso. He accompanied his uncle to jama'at meetings and ceremonies. At the age of 19, he decided to sign the bai'hat and soon afterwards to get involved in the Ahmadiyya youth section. He presents his conversion as a combination of an emotional reaction to thank his uncle and mentor, to whom he owes his education, with a rational decision after reading the founding texts of Ahmadiyya. It is the convincing logic and scientificity of Ahmadiyya's interpretations, the rationality of the Koran, the direct access to God and the centrality of the kalifate guaranteeing a clear and comforting path that attracted him. Although he was socialized in his uncle's Ahmadiyya family and gradually acquired the Ahmadiyya habitus, he describes his personal decision as decisive to join the Ahmadiyya community. During his schooling, Ibrahim had his first experience with associations by becoming an activist for the local Amnesty International group. After integrating Ahmadiyya, he chose to get involved with Humanity First. As a student at the University of Ouagadougou, he was welcomed at the mission benefitted from the support of the missionaries: "that's how it is in the jama'at, we don't leave Ahmadiyya children alone in a big city." Today, engaged in a long academic career in parallel to a professional work in an international NGO, he is still available for activities with the jama'at and assume responsibilities within Humanity First. He is now married to his girlfriend who was involved in the AEEMB, the association of Muslim pupils

14 A press review from 2010 to 2017 revealed that articles on inter-religious dialogue in the national press increased along the year 2014 marked by political tensions and insurgency, as well as in 2017 with the resurgence of terrorist attacks (Revue de presse 2018, p. 16). 
and students in Burkina Faso. During the years they spent together, she in turn became involved in Ahmadiyya, although she remained vigilant on certain issues.

Not surprisingly, Ibrahim, like other students, gains from social engagement the opportunity for developing skills or exercising responsibilities that are more difficult to acquire and exercise elsewhere. Engaging in humanitarian work as a springboard for employment is an important motivation for many young people. Ibrahim's story also shows the importance of the Ahmadiyya networks that he accessed after he integrated the movement. Feelings of solidarity and trust within the community motivate wealthy members to support their brothers, while needy or younger members of the group benefit from access to the services and goods made possible by the network, such as access to housing for Ahmadiyya students in Ouagadougou, assistance to find internships, or to join professional networks. In addition to sub-organizations by age and gender groups, there are associations within Ahmadiyya by profession. For example, the International Association of Ahmadiyya Architects and Engineers (IAAAE), the Association of Ahmadiyya Political Scientists and Lawyers, or the Association of Ahmadiyya Muslim Teachers (AMTA). These associations have an international dimension and are of particular interest to young Ahmadis at the beginning of their careers.

Humanity First's Burkinabe volunteers, current or former students, often explain their motivations for their involvement in Humanity First with the desire to serve the community by means of their professional knowledge, to thank the jama'at for the help they themselves received, and to actively participate in societal change. In Burkina Faso, where even after the political transition in $2015{ }^{15}$ expectations for improved living conditions are not being met by the new government, or are only being implemented partially and very slowly, civil society organizations such as Humanity First are seen as an opportunity to advocate change (Hagberg et al. 2017). One of the Ahmadiyya students interviewed in 2017 put it this way:

«On a marché ! On a marché fatigué ! Maintenant l'espoir est parti. En tout cas, tout seul tu ne peux rien faire. Il te faut un groupe fort qui te soutient, comme l'Ahmadiyya et qui est actif comme Humanity First. C'est comme ça que ça va bouger!»

“We walked! We walked ourselves tired! Now the hope has gone. Anyway, you can't do anything on your own. You need a strong group that supports you, like Ahmadiyya and an active active like Humanity First. That's how things will improve!"

Indeed, many observers have noted the involvement of youth in the popular uprising and of civil society organizations calling for political change and the improvement in the education and training system.

Motivations for becoming involved with Humanity First vary in France and Burkina Faso depending on the socio-political situation in the country and the personal situation of the volunteers, while the religious motive is a constant and driving force that leads to a multitude of other motives. Being involved in an NGO based on the values of Islam becomes a means of promoting compassion as another way of living one's faith, a message that aims to make citizens aware of a life based on helping others, active solidarity that expresses the fact that faith is not only to be found in the mosques.

These two individual stories, chosen to highlight trends observed throughout the data set, indicate that social engagement is presented as an adjustment between a personal story and a faith-based organization. In the profile of activists, we find people who want to "go into politics" without joining a party; who want "professional training" without enrolling in university studies; who want to "fight for women's rights" without participating in feminist networks.

The two social work actions described above and the life-stories of the converts show that the relationship with the group is structural in terms of social and religious commitment. It is precisely the centralized nature of the Ahmadi kaliphate and the transnational dimension of Humanity First that

15 Burkina Faso has in fact experienced two transitions: from 1 to 18 November 2014 under Zida and from 18 November 2014 to 28 December 2015 under Kafando. 
converts seem to value for their personal fulfilment; a strong communal and transnational construction in a society of individuals. Or, to put it another way, the combination of an individual dimension with a strong communitarian aspect.

However, beyond this accommodation between social and religious commitment, beyond the adjustment between individual aspirations and a structured and centralized religious organization, should we not detect in the facts described here emerging forms of commitment through modalities of solidarity that intersect local action of proximity with membership in transnational networks?

Affiliation to an international network is decisive for each local Humanity First group in order to carry out successful local actions. Membership in the Ahmadiyya community and Humanity First International allows for the rapid mobilization of resources far beyond local capacity and of volunteers who act collectively. The international networks allow local committees to benefit from global technical expertise and media coverage in newspapers and Ahmadiyya's own media (radio and television). By contrast, local Humanity First groups, and especially converts, bring, into the international movement, their specific needs related to the particular contexts in each country and their status as converts.

\section{Conclusions}

The central idea developed along this article has been to explore links between religious conversion and social engagement. In order to grasp these articulations, I drew on interviews and observations of Ahmadi converts to Islam engaged in humanitarian actions in France and Burkina Faso. Putting the observations made during social interventions into perspective with individual life stories makes it possible to reconstruct the plurality of commitments and the construction of multiple identities. What allows a commitment or a conversion to materialize and be maintained is certainly a matter of individual choices, which are based on a singular biographical trajectory, but it is just as much a matter of the historical, social, or religious contexts in which these motivations are grounded to reach fulfilment. The different dimensions that give meaning to a commitment in an association of solidarity and to conversion sometimes overlap: serving others, ensuring one's spiritual advancement, making sense of one's individual history as a woman, as a young person, in search of a job, or seeking political participation. Converts must use various strategies of recognition, either as individuals or as a group, which place them in a permanent negotiation with those around them. They negotiate their place with the Pakistani majority within the movement, with other Muslim currents in the country or with the secular state.

Reading conversion as negotiation allows us to understand why converts, accustomed to the recognition of otherness through their own experience as converts, become involved in civil commitments that require recognition of the value of marginalised or vulnerable people, and in a broader sense to accept the other in his or her otherness. The point is not to propose a universal theory of conversion, but to adapt the conceptual approach to a religious movement that stands out for its idiosyncratic, minority status, and with a strong communitarian tendency. Combining the two notions of conversion and negotiation allows in this precise context to refine perspectives on the civil activities of converts. Negotiation is the link that highlights an elective affinity between the intimate experience of conversion and social commitment to the other in the public space. My purpose is to underline the reciprocal fruitfulness of two notions for understanding the specificity of the status of converts in relation to other actors engaged in civil activities and, at the same time, to specify the position of converts within the religious group they join. Conversion to a minority Muslim movement, such as Ahmadiyya, raises particular issues because members of a minority have different priorities from those of the religious majority, especially in terms of recognition. In France, the Ahmadiyya Muslim community faces a two-fold minority situation, within Islam and within a Christian majority. In Burkina Faso and France, a third minority situation adds up, as they constitute a minority within the movement itself. 
In France, where the Ahmadi community is still relatively small, involvement in the NGO enables some of the converts to assert themselves in relation to the prevailing Pakistani Ahmadis. The commitment within a humanitarian organization founded by the Ahmadiyya leader seems to them more adapted to show and practise the "true face" of Islam detached from Pakistani culture and to combine religious and social commitment.

In Burkina Faso, involvement in the NGO allows converts to connect their personal and professional aspirations to an engagement for the development of the country and in favour of vulnerable populations, sometimes coupled with political activism.

For a religious minority, participation in development and solidarity networks can be a means for establishing itself as a legitimate and valuable member of society, so that potential converts can be solicited according to their personal priorities within a pluralistic religious landscape. Social actions in the public sphere make it possible to initiate a real reflection on the place and role of a minority religion that asserts itself in France and Burkina Faso as a social actor, without having any official recognition from the umma.

Funding: The data for this article was collected along different research projects funded by the German Research Foundation (DFG), grant number LA 2772/3-1, the Gerda Henkel Foundation, grant number AZ 04/IS/13, and the Bureau Central des Cultes, French Ministry of Interior, grant number n ${ }^{\circ}$ 41/2019.

Acknowledgments: I am grateful to many Ahmadis in Germany, France, Burkina Faso, Benin, and Ghana, and particularly to the Humanity First teams in France and Germany for the time that they devoted to my enquiry and for their kindness in answering all my questions. I thank Adjara Konkobo for the transcriptions of the recorded interviews. Sébastien Le Pipec polished my very German formulations into proper English and never hesitated to offer insightful suggestions. Finally, I am particularly indebted to Mahamadi Ouédraogo for his invaluable assistance and active interest in my field research in Burkina Faso.

Conflicts of Interest: The author declares no conflict of interest. The funders had no role in the design of the study; in the collection, analyses, or interpretation of data; in the writing of the manuscript, or in the decision to publish the results.

\section{References}

Adams, Vincanne. 2013. Markets of Sorrow, Labors of Faith: New Orleans in the Wake of Katrina. Durham: Duke University Press.

Ahmed, Munir D. 2012. Studien zur Ahmadiyya. Ein Fall Religiöser Diskriminierung in Pakistan. Leipzig: Fazli Books. Allahayari, Rebecca Anne. 2000. Visions of Charity. Berkeley: University of California Press.

Allievi, Stefano. 1999. Pour une sociologie des conversions: Lorsque des Européens deviennent musulmans. Social Compass 46: 283-301. [CrossRef]

Audet Gosselin, Louis, and Kathéry Couillard. 2019. ONG confessionnelles au Burkina Faso. In Rencontres Religieuses et Dynamiques Sociales au Burkina Faso. Edited by Alice Degorce, Ludovic Kibora and Katrin Langewiesche. Dakar: Editions Amalion, pp. 225-45.

Balzani, Marzia. 2010. Dreaming, Islam and the Ahmadiyya Muslims in the UK. History and Anthropology 21: 293-305. [CrossRef]

Beckford, James A. 1989. Religion and Advanced Industrial Society. London and Boston: Unwin Hyman.

Benthall, Jonathan, and Jérôme Bellion-Jourdan. 2003. The Charitable Crescent. Politics of Aid in the Muslim World. London: Tauris.

Benthall, Jonathan. 2005. L'humanitarisme islamique. Cultures et Conflits 60: 103-22. [CrossRef]

Bertaux, Daniel. 1980. L'approche biographique: Sa validité méthodologique, ses potentialités. Cahiers Internationaux de Sociologie 69: 197-225.

Blakely, Thomas D., Walter E. A. Van Beek, and Dennis L. Thomson, eds. 1994. Religion in Africa. London: James Curry.

Bornstein, Erica. 2003. The Spirit of Development: Protestant NGOs, Morality, and Economics in Zimbabwe. New York and London: Routledge.

Bouzar, Dounia. 2001. L'islam des Banlieues. Les Prédicateurs Musulmans: Nouveaux Travailleurs Sociaux? Paris: Éditions Syros. 
Brodard, Baptiste. 2011. De L'inscription Communautaire à L'affirmation sur la Scène Sociale. L'action Sociale Musulmane en Région Parisienne. Master's thesis, Faculté des Lettres de l'Université de Fribourg, Fribourg, Switzerland.

Casanova, José. 1994. Public Religions in the Modern World. Chicago: University of Chicago Press.

Cissé, Issa, and Katrin Langewiesche. 2019. L'Association Islamique Ahmadiyya au Burkina Faso. In Rencontres Religieuses et Dynamiques Sociales au Burkina Faso. Edited by Kibora Degorce, Ludovic Ouhonyioué Kibora and Katrin Langewiesche. Dakar: Editions Amalion, pp. 90-107.

Coleman, Simon. 2000. The Globalisation of Charismatic Christianity: Spreading the Gospel of Prosperity. Cambridge: Cambridge University Press.

Comaroff, Jean, and John L. Comaroff. 1991. Of Revolution and Revelation. Christianity, Colonisation and Consciousness in South Africa. Chicago and London: University of Chicago Press.

de Terssac, Gilbert. 2003. La théorie de la Régulation Sociale de Jean-Daniel Reynaud. Paris: La Découverte.

Diop, Moustapha. 1989. Immigration et religion: Les musulmans négro-africains en France. Migration Société I: 45-57.

Duclos, Bénédicte Harvard, and Sandrine Nicourd. 2005. Pourquoi s'engager? Bénévoles et Militants dans les Associations de Solidarité. Paris: Payot.

Ewing, Katherine Pratt. 2015. 'Islam Is Not a Culture': Reshaping Muslim Publics for a Secular World. In Religion in Diaspora: Cultures of Citizenship. Edited by Sondra L. Hausner and Jane Garnett. London: Palgrave Macmillan, pp. 202-25.

Freeman, Deena. 2012. Pentecostalism and Development Churches, NGOs and Social Change in Africa. New York: Palgrave Macmillan.

Frégosi, Franck. 2009. Formes de mobilisation collective des musulmans en France et en Europe. Revue Internationale de Politique Comparée 16: 41-61.

Galonnier, Juliette, Amélie Puzenat, Hamzi Khateb, and Géraldine Mossière. 2019. Introduction: Conversions à l'islam. Archives de Sciences Sociales des Religions 186: 11-31.

Gifford, Paul. 2004. Ghana's New Christianity. In Pentecostalism in a Globalising African Economy. London: Hurst.

Gifford, Paul. 2015. Christianity, Development and Modernity in Africa. London: Hurst.

Habermas, Jürgen. 1992. “L'espace public”, 30 ans après. Quaderni 18: 161-91. [CrossRef]

Hagberg, Sten, Ludovic Kibora, Sidi Barry, Siaka Gnessi, and Adjara Konkobo. 2017. Transformations Sociopolitiques Burkinabè de 2014 à 2016. Africa Studies. Uppsala: Uppsala University.

Hanson, John H. 2017. The Ahmadiyya in the Gold Coast: Muslim Cosmopolitans in the British Empire. Bloomington: Indiana University Press.

Hefner, Robert W., ed. 1993. Conversion to Christianity. Oxford: University of California Press.

Hervieu-Léger, Danièle. 1999. Le Pèlerin et le Converti. La Religion en Mouvement. Paris: Flammarion.

Holder, Gilles, ed. 2009. L'Islam en Afrique: Vers un Espace Public Religieux? Paris: Karthala.

Jonathan, Laurence, and Juston Vaïsse. 2007. Intégrer l'Islam. Paris: Odile Jacob.

Jonker, Gerdien. 2016. The Ahmadiyya Quest for Religious Progress: Missionizing Europe 1900-1965. Leiden: Brill.

Jules-Rosette, Benetta. 1975. African Apostles: Ritual and Conversion in the Church of John Maranke. Ithaca: Cornell University Press.

Kepel, Gilles. 1991. La revanche de Dieu: Chrétiens, juifs et musulmans à la reconquête du monde. Paris: Éditions du Seuil.

Keynote address at the International Conference of Humanity First in the Baitul Futuh Mosque (UK). 2015. Available online: https://www.khalifatulmasih.org/press-releases/head-ahmadiyya-muslim-communityaddresses-humanity-first-international-conference/ (accessed on 23 May 2020).

Kroessin, Mohamed Ralf. 2009. Mapping UK Muslim Development NGOs. Working Paper 30. Birmingham: University Birmingham.

Lahlou, Rachid. 2018. Un Humanitaire Musulman dans la République. Paris: Ateliers Henry Dougier.

Langewiesche, Katrin. 1998. Des conversions réversibles: Études de cas dans le nord-ouest du Burkina Faso. Parcours de conversion. Journal des Africanistes 68: 47-65. [CrossRef]

Langewiesche, Katrin. 2003. Mobilité Religieuse. Changements Religieux au Burkina Faso. Hamburg, Berlin and Münster: LIT-Verlag. 
Langewiesche, Katrin. 2011. Konfessionell, national, global: Das Gesundheitswesen in Burkina Faso aus historischer Perspektive. In Auf dem Boden der Tatsachen. Festschrift für Thomas Bierschenk. Edited by Nikolaus Schareika, Eva Spies and Pierre-Yves Le Meur. Köln: Rüdiger Köppe Verlag, pp. 415-34.

Langewiesche, Katrin. 2020a. Le calife et son portrait. L'iconographie d'un Islam missionnaire. In Matérialités Religieuses. Aux frontières du Public et du Privé. Edited by Ba Mame-Penda, Saint-Lary Maud and Samson Fabienne. Dakar: édition Codesria, forthcoming.

Langewiesche, Katrin. 2020b. Ahmadiyya and development aid in West Africa. In Does Religion make a Difference? Religious NGOs in International Development Collaboration. Edited by Andreas Heuser and Jens Köhrsen. Baden-Baden: Nomos, pp. 263-86.

Langewiesche, Katrin. 2020c. Politics of Humanitarianism. The Ahmadiyya and the provision of Social Welfare. In Muslim Faith-Based Organizations and Social Welfare in Africa. Edited by Holger Weiss. London: Palgrave Macmillan, forthcoming.

Lathan, Andrea. 2008. The Relativity of Categorizing in the Context of the Ahmadiyya. Welt des Islams 48: 372-93. [CrossRef]

Lathan, Andrea. 2010. Reform, Glauben und Entwicklung: Die Herausforderungen für die Ahmadiyya-Gemeinde. In Islam in Europa: Religiöses Leben Heute. Ein Portrait Ausgewählter Islamischer Gruppen und Institutionen. Edited by Dietrich Reetz. Münster: Waxmann, pp. 79-107.

Le Pape, Loïc. 2007. Engagement religieux, engagements politiques. Archives de Sciences Sociales des Religions 140: 9-27. [CrossRef]

LeBlanc, Marie Nathalie. 2012. Du militant à l'entrepreneur: Les nouveaux acteurs religieux de la moralisation par le bas en Côte d'Ivoire. Cahiers d'études Africaines 206-207: 493-516. [CrossRef]

Lofland, John, and Rodney Stark. 1965. Becoming a world-saver: A theory of conversion to a deviant perspective. American Sociological Review 30: 862-74. [CrossRef] [PubMed]

Martens, Silvia. 2014. Muslim Charity in a Non-Muslim Society. Journal of Muslims in Europe 3: 94-116. [CrossRef]

Mary, André. 1998. Retour sur la conversion africaine: A propos de Horton, Peel et les autres. Journal des Africanistes 68: 11-20. [CrossRef]

Meintel, Deirdre. 2003. La stabilité dans le flou: Parcours religieux et identité de spiritualistes. Anthropologie et Sociétés 27: 35-64. [CrossRef]

Minahan, James. 2002. Encyclopedia of the Stateless Nations. Ethnic and National Groups Around the World. Vol I. London: Greenwood Press.

Molokotos-Liederman, Lina, Anders Bäckström, and Grace Davie, eds. 2018. Religion and Welfare in Europe. Gendered and Minority Perspectives. Bristol: Policy Press.

Mossière, Géraldine. 2009. Des femmes converties à l'islam en France et au Québec: Religiosités d'un nouveau genre. Ph.D. dissertation, University of Montréal, Montréal, QC, Canada.

Ozkan, Mehmet. 2012. Transnational Islam, Immigrant NGOs and Poverty Alleviation: The Case of the IGMG. Journal of International Development 24: 467-84. [CrossRef]

Peel, John D. Y. 1990. The pastor and the babalawo: The interaction of religions in nineteenth-century Yorubaland. Africa 60: 338-69. [CrossRef]

Petersen, Marie-Juul. 2015. For Humanity or for the Ummah: Aid and Islam in Transnational Muslim NGOs. London: Hurst.

Pilon, Marc, Alice Degorce, and Katrin Langewiesche. 2019. Les enjeux des chiffres: La démographie des religions au Burkina Faso. In Rencontres Religieuses et Dynamiques Sociales au Burkina Faso. Edited by Kibora Degorce, Ludovic Ouhonyioué Kibora and Katrin Langewiesche. Dakar: Editions Amalion, pp. 165-95.

Poirier, Jean. Simone Clapier-Valladon, and Paul Raybaut. 1983. Les Récits de vie. Théorie et Pratique. Paris: PUF.

Revue de presse. 2018. La Perception du Religieux au Burkina Faso à Travers des Articles de Presse (2010-2017). Programme «État des lieux des Connaissances sur les Religions au Burkina Faso», Document de Travail. Ouagadougou: IRD.

Quiminal, Catherine, and Mahamet Timéra. 2002. 1974-2002, les mutations de l'immigration ouest-africaine. Hommes et Migrations 1239: 19-32. [CrossRef]

Sadouni, Samadia. 2009. Humanisme spiritual et ONG islamiques. Afrique Contemporaine 231: 155-70. [CrossRef]

Salvatore, Armando. 2005. Making Public Space: Opportunities and Limits of Collective Action among Muslims in Europe. Journal of Ethnic and Migration Studies 30: 1013-31. [CrossRef] 
Savadogo, Mathias, Muriel Gomez-Perez, and Marie Nathalie LeBlanc. 2016. Reflections on the Socio-political Roles of Islamic NGOs in West Africa: Senegal, Côte d'Ivoire and Burkina Faso. In Faith and Charity. Religion and Humanitarian Assistance in West Africa. Edited by Marie Nathalie LeBlanc and Louis Audet Gosselin. London: Pluto Press, pp. 27-46.

Schurmans, Marie-Noëlle. 2013. Négociations et transactions: Un fondement socio-anthropologique partagé. Négociations 20: 81-93. [CrossRef]

Setta, El-Houari. 1999. Le Suisse converti à l'islam: émergence d'un nouvel acteur social. Social Compass 46: $337-49$. [CrossRef]

Skinner, David E. 2010. Da'wa and Politics in West Africa: Muslim Jama'at and Non-Governmental Organisations in Ghana, Sierra Leone and the Gambia. In Development and Politics from Below: Exploring Religious Spaces in the African State. Edited by Barbara Bompani and Maria Frahm-Arp. London: Palgrave, pp. 99-130.

Snow, David A., and Cynthia L. Phillips. 1980. The Lofland-Stark Conversion Model: A Critical Reassessment. Social Problems 27: 430-47. [CrossRef]

Soares, Benjamin, and Marie Nathalie LeBlanc. 2015. Islam, jeunesse et les trajectoires de mobilisation en Afrique de l'Ouest dans l'ère néolibérale: Regard anthropologique. In Mobilisations Collectives en Afrique. Edited by Kadja Tall. Leiden: Brill, pp. 67-90.

Sounaye, Abdoulaye. 2011. Doing Development the Islamic Way in Contemporary Niger. Bulletin de l'APAD 33: 61-90.

Thelen, Tatjana, Caroline Lautloff-Grandits, and Anja Peleikis. 2009. Social Security in Religious Networks. An Introduction. In Social Security in Religious Networks. Edited by Caroline Lautloff-Grandits, Anja Peleikis and Tatjana Thelen. New York: Berghahn Books, pp. 1-15.

Thuderoz, Christian. 2009. Régimes et registres de négociation. Négociations 2: 107-18. [CrossRef]

Timera, Mahamet. 1997. Les associations de femmes africaines: Un creuset d'intégration. Revue Française des Affaires Sociales 2: 159-65.

Van Der Veer, Peter. 1996. Conversion to Modernities. The Globalisation of Christianity. London: Routledge.

Vitale, Mara. 2019. L'islam confrérique de la tijâniyya et l'hamawiyya. In Rencontres Religieuses et Dynamiques Sociales au Burkina Faso. Edited by Kibora Degorce, Ludovic Ouhonyioué Kibora and Katrin Langewiesche. Dakar: Editions Amalion, pp. 41-55.

Weiss, Holger, ed. 2020. Muslim Faith-Based Organizations and Social Welfare in Africa. New York: Palgrave Macmillan.

Wohlrab-Sahr, Monika. 1999. Konversionen zum Islam in Deutschland und den USA. Frankfurt and New York: Campus Verlag.

(C) 2020 by the author. Licensee MDPI, Basel, Switzerland. This article is an open access article distributed under the terms and conditions of the Creative Commons Attribution (CC BY) license (http://creativecommons.org/licenses/by/4.0/). 